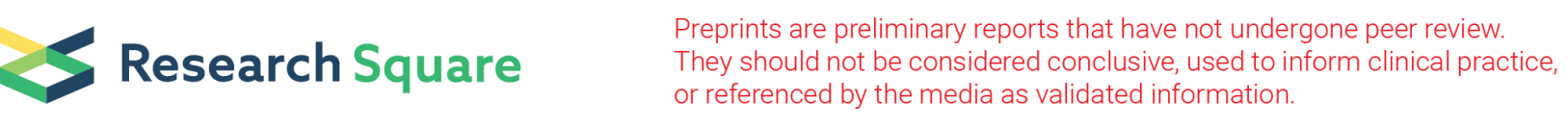

\title{
A comparison of immunohistochemistry and mass spectrometry for determining light chain amyloid fibril protein from formalin-fixed renal biopsy tissue in a single Chinese center
}

\author{
Ying Sun \\ Peking Union Medical College Hospital \\ Jian Sun \\ Peking Union Medical College Hospital \\ Wei Sun \\ Chinese Academy of Medical Sciences \\ Junyi Pang \\ Peking Union Medical College Hospital \\ Yubing Wen \\ Peking Union Medical College Hospital \\ Zixuan Zhu \\ Peking Union Medical College Hospital \\ Jianling Tao \\ Stanford University \\ Limeng Chen \\ Peking Union Medical College Hospital \\ Xuemei Li \\ Peking Union Medical College Hospital \\ Mingxi Li ( $\nabla$ mingxili@hotmail.com ) \\ Peking Union Medical College Hospital https://orcid.org/0000-0002-1876-4186
}

Research article

Keywords: Amyloidosis, Proteomic analysis, Renal biopsy

Posted Date: August 15th, 2019

DOI: https://doi.org/10.21203/rs.2.13027/v1

License: () This work is licensed under a Creative Commons Attribution 4.0 International License. Read Full License 


\section{Abstract}

Background Amyloidosis, a disease caused by abnormal protein deposition in tissues, is classified according to the protein precursor that form amyloid fibrils. Diagnosis of amyloidosis is type-specific as the identification of amyloid protein determines the following treatment. However, around a quarter of amyloidosis cases cannot be accurately subtyped by most commonly used immunohistochemistry (IHC). In order to obtain precise diagnosis, our study is focusing on another protein identification methods, laser microdissection and mass spectrometry (LDMS). Methods 20 cases of Amyloid Light-chain (AL) amyloidosis without further subtype were included. IHC and LDMS were used to detect light chains on formalin-fixed paraffin-embedded (FFPE) tissues from renal biopsy. Results $100 \%$ consistence between positive IHC and LDMS results were observed, however, chances of subtyping using LDMS is increased to $94 \%$ compared to IHC which is only $76 \%$. Conclusion LDMS is a valuable tool in regard to subtyping amyloidosis.

\section{Background}

Amyloid is characterized by its fibrillar protein deposition in tissues, giving off green birefringence under crosspolarized light when stained with Congo red. ${ }^{1}$ Researches have shown that amyloid is rather a group of diseases as more than 30 proteins can form amyloid fibrils ${ }^{2}$. The crucial step of amyloid diagnosis is identification of the pathogenic amyloid fibril protein for each case, as the following treatment depends on it to postpone, even reverse the progressive and fatal condition ${ }^{1}$.

As the most widely used method to determine amyloid fibril protein in clinical practice, $\mathrm{IHC}$ is considered quick and easy to perform, but its sensitivity and specificity are unstable and largely dependent on the antibody quality ${ }^{3,4}$, problems like masking of epitopes within misfolding fibril protein still result in false negative results in certain cases ${ }^{5}$. Researchers have subsequently searched for other methods.

Laser microdissection and tandem mass spectrometry (LDMS) is particularly promising since only a small quantity of formalin-fixed amyloidotic tissue is required ${ }^{6}$. Moreover, other methods for identifying the amyloid fibril protein, such as electron microscopy (EM) with immunogold, are expensive and require a high level of expertise ${ }^{7}$. Mayo clinic ${ }^{5}$ has been using this method to evaluate and solve the misdiagnosis of difficult and complicated amyloid cases, but there is no such a study in Chinese population yet, and the feasibility of LDMS in this field has not been studied in China. Our

group has been focusing on using proteomics in renal disease studies ${ }^{8}$. The aim of this study was to compare IHC and LDMS in subtyping AL proteins and determine the role of proteomic analysis for the diagnosis of AL amyloidosis. We aim to find out if LDMS could be an alternative method in amyloid subtype diagnosis, and its value of clinical application.

\section{Methods}

Patients and Study plan

From electronic medical records, we collected data on patients diagnosed with renal amyloidosis from Peking Union Medical College Hospital (PUMCH) during 1994 to 2015. The diagnosis of renal amyloidosis based on renal biopsy 
pathology study by staining renal biopsy frozen tissue with direct immunofluorescence (incubated with fluorescently labeled primary antibody at $37^{\circ} \mathrm{C}$ for $30 \mathrm{~min}$, washed with normal saline I and II for $5 \mathrm{~min}$, blocked with glycerol diluent, and refrigerated at $4^{\circ} \mathrm{C}$.) For light microscopy, $2 \mu \mathrm{m}$ slides were cut from FFPE renal biopsy tissues and routinely stained. An experienced pathologist examined at least eight sections for each case. Renal amyloidosis was confirmed by positive Congo red stain and EM examination (representative EM images are shown in Figure 1). Clinical records of selected patients were also collected and reviewed.

\section{Positive and Negative Control Selection}

Positive controls: The positive controls were $4 \mathrm{AL}$ amyloid patients' FFPE tissues with consistent results of blood/urine electrophoresis and immunofixation, as well as direct immunofluorescence of fresh frozen tissue from renal biopsy.

Negative controls: A candidate specimen for the negative control was the kidney removed from radical nephrectomy. Tissue at the far end of the removed kidney was formalin-fixed and stained with hematoxylin and eosin, periodic acidSchiff, periodic acid-silver metheramine and Masson trichrome for light microscopy inspection. We used 4 specimens of normal kidney tissue as negative controls.

\section{Pathological Study of Kidney Tissue}

Based on the routine pathology examination mentioned in Patient and Study Plan, our study took 5 extra serial sections from a single block, including 3 sections of $8 \mu \mathrm{m}$ thick for Congo Red staining and LDM/MS, and 2 sections of $2 \mu \mathrm{m}$ thick for IHC.

\section{Immunohistochemistry}

IHC was performed on serial sections using standard methods in 20 patients with $\mathrm{AL}$ amyloidosis who underwent renal biopsy, including 4 positive controls, and 4 negative controls. 2- $\mu \mathrm{m}$ sections from paraffin-embedded tissue were deparaffinized and rehydrated. Sections were incubated by Pepsin for $30 \mathrm{~min}$ at $37^{\circ} \mathrm{C}$ to expose antigen. After incubation with $0.3 \% \mathrm{H}_{2} \mathrm{O}_{2}$ for 10 mins, the specimen was incubated with the primary antibody (Mouse anti-Lambda Light Chain Monoclonal Antibody, Mouse anti-Kappa Light Chain Monoclonal Antibody, Zsbio, China) for 100 mins at $37^{\circ} \mathrm{C}$, then incubated with anti-mouse IgG (ImmunoReagents, USA) for 30 mins at room temperature.

\section{Laser microdissection and proteomic study}


Each 8- $\mu$ m-thick section of FFPE tissues was stained with Congo red then micro dissected using Leica DM 5600 (shown in Figure 2). Micro dissected material fell into microcentrifuge tubes containing Tris/EDTA/0.002\% Zwittergent buffer, heated at $100^{\circ} \mathrm{C}$ for 60 mins. After 40 mins of sonication in a water bath at $60^{\circ} \mathrm{C}$, samples were digested by trypsin with a microwave oven under $850 \mathrm{~W}$ for two rounds of 1 min each round ${ }^{9,10}$.

Peptide mixtures were desalted by ZipTip Micro-C18 pipette tips (Millipore, Bedford, MA, USA), then separated by a nanoflow high pressure liquid chromatography (HPLC, NanoAcquity system from Waters, Milford, US-MA), and analyzed by tandem MS (Liquid Chromatography-MS/MS) by a Linear Trap Quadrupole Orbitrap Velos Pro (ThermoFisher instruments, San Jose, US-CA).

Protein identification was carried out by Mascot (Matrix Science, London; version 2.3.02) using UniProt human (www.uniprot.com) as database with peptide ion tolerance of $0.05 \mathrm{Da}$, trypsin two missed cleavages maximum and carbamidomethylation fixed modification. Search results then filtered by Scaffold (v 4.3.2) through decoy database, proteins were accepted with less than $1 \%$ false discovery rate at protein level and at least two unique peptides detected. emPAl was used as a quantitative parameter to compare identified proteins' abundance ${ }^{11,12}$.

\section{LDMS/MS Diagnosis and subTyping of Amyloidosis}

For each case, amyloid-associated proteins, such as $\mathrm{K}, \lambda$, immunoglobulin heavy chain, and fibrinogen-a were screened from proteomics study protein results. The diagnosis of amyloidosis at the proteomic level using LDMS/MS was based on the presence of serum amyloid protein and apolipoprotein E. Quantitative information on each protein was based on the LDMS/MS results, and subtyping of amyloidosis was based on the greatest abundance of protein that corresponded to the specific type of amyloid ${ }^{6}$.

\section{Results}

\section{Clinical Features and amyloidosis associated inspection results}

Based on the pathologic study of renal biopsy, there were 59 patients diagnosed with amyloidosis, 42 of whom had positive serum IFE results with kappa or lambda M protein. Among these 42 patients, the renal biopsy direct immunofluorescence staining results in 8 cases comply with serum IFE results; renal biopsy direct immunofluorescence staining results in 34 cases do not comply with their serum IFE results. We chose 20 cases with ample renal biopsy tissue from those 34 cases and performed both light chain IHC and LDMS to confirm the subtype of amyloidosis. Flow chart of patient selection is shown in Table 1.

The clinical diagnosis and renal biopsy results of 20 patients without evidence of AL amyloidosis-including no structural deposition sites under HE staining, direct immunofluorescent staining, and electron microscopy site deposition-are shown in Table 2. 
Immunohistochemical Results

Among the 20 patients, 11 had the same immunohistochemical staining results as blood/urine immunofixation electrophoresis with sensitivity of 55\%; 9 patients had the same light chain staining intensity and could not distinguish between $A L-\lambda$ and $A L-K$. In four positive controls, two were $\kappa$ positive and two were $\lambda$ positive; these results are consistent with their IEF and renal biopsy fresh frozen tissue direct immunofluorescence results. Four negative controls did not stain with $\mathrm{K}$ or $\lambda$.

\section{Proteomics Subtype}

20 renal biopsy specimens were analyzed in this study. Figure 3-4 shows LDMS/MS results of AL-K, AL- $\lambda$ cases. There was a good concordance between IHC and LDMS with respect to identification of the amyloid fibril protein among 11 biopsies (Patient number $3,4,5,6,9,11,13,14,16,19,20)$. In total, 9 of $20(45 \%)$ cases had both $\mathrm{k}$ and $\lambda$ positive stains, so the diagnosis of amyloidosis could not be confirmed by IHC alone. LDMS diagnosed 18 of these 20 cases (90\%), confirming AL amyloid. Clinical features and LDMS/MS subtyping results of the 20 chosen patients are shown in Table 2. The results of four positive controls showed two cases that were $\mathrm{k}$ positive and two that were $\lambda$ positive, consistent with the IHC, IEF and renal biopsy fresh frozen tissue direct immunofluorescence results. Proteomic study did not detect serum amyloid protein or apolipoprotein $\mathrm{E}$ in four negative controls.

\section{Discussion}

Amyloidosis is a group of heterogeneous diseases, which are formed by mis-folding of precursor protein monomer into the $\beta$-lamellar structure and forming the original fibers deposited in the extracellular matrix, which destroys the tissue structure and leads to organ dysfunction ${ }^{1}$. At present, more than 30 kinds of precursor protein which can form amyloid fiber are found in the human body. More than 10 kinds of this protein can lead to systemic amyloidosis, which affect several organs, such as heart, kidney , etc ${ }^{6}$. It is a common sense among nephrologists and pathologists that diagnosis of amyloid using Congo red must be followed by the confirmation of the morbigenous protein's chemical nature. IHC is surely an easy, popular and affordable routine procedure to serve the purpose, most cases of amyloidosis can be classified by immunofluorescence, immunohistochemistry and other methods, but there are still a few patients with unclear classification. The LDMS was used as a complimentary technique. Sethi et al. analyzed 74 cases of renal amyloidosis with no definite subtype by LDMS and found that nearly half of the cases were Al-type amyloidosis, followed by the LECT2 type and AA type ${ }^{5}$. In 2015, a study compared the results of IHC and LDMS in 147 cases of amyloidosis, and the results showed that LDMS had higher specificity than immunohistochemistry. The failure of LDMS subtyping was due to insufficient tissue mass, but LDMS was more sensitive and specific to the diagnosis of amyloidosis than $\mathrm{IHC}^{13}$. 
However, no such study has been carried out in Chinese population to verify the proteomic composition of amyloid renal biopsy tissue. Consistent with Sethi's study, we confirmed the presence of SAP, APOE and Ig Kappa light in positive control specimens; while in negative controls, no SAP, APOE or amyloid precursor proteins were detected. We found that 18 of 20 cases (90\%) were finally analyzed as Al-type through LDMS. In 9 patients whose subtype cannot be confirmed by immunohistochemistry, 6 cases were identified by mass spectrometry with immunoglobulin $\mathrm{k}$ or $\lambda$ light chain. The results were consistent with the blood or urine immuno-stationary electrophoresis, suggesting that the method could provide a classification diagnosis for cases of immunohistochemical failure. There may be several defects in our IHC methodology, such as we used native light chain antibody, but still, LDMS as a complimentary diagnostic method is proved to be effective and could be carried out in renal biopsy tissue in China.

Although immunohistochemistry is routinely used to identify amyloid proteins for its economic feature, its dependence on feasible antibody restricts its capability in differentiating proteins. Right now, antibodies for most known amyloid proteins are not available and there are unknown amyloid proteins with no antibodies at all. MS-based proteomics is a newer technology intended to identify the entire proteome of the targeted tissue; it can identify unknown proteins and does not depend on antibodies. But as MS-based technology is expensive and need a high level of expertise, at present the LMD/MS technique is considered as a supplement to the diagnosis of amyloidosis ${ }^{14}$. The method is applicable to cases of negative or ambiguous immunohistochemistry results, the rare type of amyloidosis, and to confirm immunofluorescence or immunohistochemical results ${ }^{15-17}$.

We had 2 failed cases in LDMS study, possibly due to the lack of positive area of Congo red staining, the contamination of blood source proteins, or the inhibition of target protein detection from other proteins. It is necessary to improve the protein extraction technique and to improve the accuracy of mass spectrometry by reducing blood contamination.

To our knowledge, this is the first study in China to evaluate the feasibility of LDMS on amyloid protein classification. This study has several defects, such as we only included light chain amyloid cases, the number of samples is limited in the study, and the IFE test results were not so convincing (this test was still under trial at that period in our hospital).

\section{Conclusions}

In this study, we proved that the LDMS is a complementary diagnostic method for amyloidosis, and the application of LDMS will be beneficial for diagnosis of difficult and complicated cases. It has been reported that the newly discovered renal leukocyte chemotactic factor 2 amyloidosis is the second most common form of amyloidosis as a whole and is particularly common in Hispanic patients from the Southwest United States, showing the nature of amyloidosis might vary depending upon the geographic location and ethnic makeup of the patient population ${ }^{18}$. So it is very important to explore the mechanical nature and prognosis in different amyloidosis among various populations. In order to avoid misdiagnosis and determine rare types of amyloidosis, further research should be carried out in a Chinese population. As we already have the expertise of LDMS in processing renal biopsy tissue, we are capable to carry out this research.

This study helps to diagnose the type of amyloid in a substantial portion of patients where the IEF is not reliable, and is a good contribution to our knowledge about renal amyloidosis especially in Chinese population. 


\section{Abbreviations}

Immunohistochemistry, IHC

Laser microdissection and mass spectrometry, LDMS

Amyloid Light-chain, AL

Formalin-fixed and paraffin-embedded, FFPE

Electron microscopy, EM

\section{Declarations}

We are gratefully to Zhengguang Guo and Haidan Sun for their assistance on data analysis.

Ethics approval and consent to participate

The protocol of the study was approved by the Ethics Committee of PUMCH (JS-1233-1). Informed prior consent was obtained in written format from each subject. Electronic data collection was approved by PUMCH.

Consent for publication

Not applicable.

Availability of data and material

This article is distributed under the terms of the Creative Commons Attribution 4.0 International License (http://creativecommons.org/licenses/by/4.0/), which permits unrestricted use, distribution, and reproduction in any medium, provided you give appropriate credit to the original author(s) and the source, provide a link to the Creative Commons license, and indicate if changes were made. The Creative Commons Public Domain Dedication waiver (http://creativecommons.org/publicdomain/zero/1.0/) applies to the data made available in this article, unless otherwise stated.

Competing interests

The authors declare that they have no competing interests.

Funding

This research was funded by the National Key Research and development Program of China (2016YFC0901500). 
Authors' contributions

YS and MXL conceived and designed the experiments. YS and ZXZ acquired patients' clinical data. YS and JYP performed immunostaining. YS and JS finished microdissection. YS and WS conducted proteomic analysis. YBW gave renal pathology diagnosis. JLT, LMC, XML and $M X L$ gave professional opinions and suggestions during the research. YS and MXL wrote and revised the manuscript. All authors read and approved the final manuscript.

\section{References}

[1] Merlini G, Bellotti V: Molecular mechanisms of amyloidosis. N Engl J Med 2003, 349:583-96.

[2] Sipe JD, Benson MD, Buxbaum JN, Ikeda SI, Merlini G, Saraiva MJ, et al. Amyloid fibril proteins and amyloidosis: chemical identification and clinical classification International Society of Amyloidosis 2016 Nomenclature Guidelines. Amyloid 2016, 23:209-13.

[3] Kebbel A, Rocken C. Immunohistochemical classification of amyloid in surgical pathology revisited. Am J Surg Pathol 2006, 30:673-83.

[4] Satoskar AA, Burdge K, Cowden DJ, Nadasdy GM, Hebert LA, Nadasdy T. Typing of amyloidosis in renal biopsies: diagnostic pitfalls. Arch Pathol Lab Med 2007, 131(6):917-22.

[5] Said SM, Sethi S, Valeri AM, Leung N, Cornell LD, Fidler ME, et al. Renal amyloidosis: origin and clinicopathologic correlations of 474 recent cases. Clin J Am Soc Nephrol 2013, 8:1515-23.

[6] Sanjeev Sethi, Jason D Theis, Nelson Leung, Anjali Sethi, Samih H Nasr, Fernando C Fervenza, et al. Laser microdissection and mass spectrometry-based proteomics aids the diagnosis and typing of renal amyloidosis. Kidney Int 2012 Jul, 82.

[7] Sliver MM, Heam SA, Walton JC, Lines LA, Walley VM. Immunogold quantitation of immunoglobulin light chains in renal amyloidosis and kappa light chain nephropathy. Am J Pathol 1990, 136(5):997-1007.

[8] Guo Z, Liu X, Li M, Shao C, Tao J, Sun W, Li M. Differential urinary glycoproteome analysis of type 2 diabetic nephropathy using 2D-LC-MS/MS and iTRAQ quantification. Journal of translational medicine 2015, 13:371.

[9] Sun W, Sun J, Zou L, Shen K, Zhong D, Zhou D, Sun W, et al. The Successful Diagnosis and Typing of Systemic Amyloidosis Using A Microwave-Assisted Filter-Aided Fast Sample Preparation Method and LC/MS/MS Analysis. PloS one $2015,10: \mathrm{e} 0127180$.

[10] Kakimoto Y, Tsuruyama T, Yamamoto T, Furuta M, Kotani H, Ozeki M, et al. Novel in situ pretreatment method for significantly enhancing the signal in MALDI-TOF MS of formalin-fixed paraffin-embedded tissue sections. PloS one 2012, 7:e41607.

[11] Ishihama Y, Oda Y, Tabata T, Sato T, Nagasu T, Rappsilber J, et al. Exponentially modified protein abundance index (emPAl) for estimation of absolute protein amount in proteomics by the number of sequenced peptides per protein. 
Molecular \& cellular proteomics : MCP 2005, 4:1265-72.

[12] Shinoda K, Tomita M, Ishihama Y. emPAI Calc-for the estimation of protein abundance from large-scale identification data by liquid chromatography-tandem mass spectrometry. Bioinformatics (Oxford, England) 2010, 26:576-7.

[13] Gilbertson JA, Theis JD, Vrana JA, Lachmann H, Wechalekar A, Whelan C, et al. A comparison of immunohistochemistry and mass spectrometry for determining the amyloid fibril protein from formalin-fixed biopsy tissue. J Clin Pathol 2015, 68:314-7.

[14] Picken MM. Proteomics and mass spectrometry in the diagnosis of renal amyloidosis. Clin Kidney J 2015, 8:66572.

[15] Sethi S, Theis JD, Leung N, Dispenzieri A, Nasr SH, Fidler ME, et al. Mass spectrometry-based proteomic diagnosis of renal immunoglobulin heavy chain amyloidosis. Clin J Am Soc Nephrol 2010, 5:2180-7.

[16] Saha A, Chopra Y, Theis JD, Vrana JA, Sethi S. AA amyloidosis associated with systemic-onset juvenile idiopathic arthritis. Am J Kidney Dis 2013, 62:834-8.

[17] Larsen CP, Kossmann RJ, Beggs ML, Solomon A, Walker PD. Clinical, morphologic, and genetic features of renal leukocyte chemotactic factor 2 amyloidosis. Kidney international 2014, 86:378-82.

\section{Tables}

Table 1. Flow chart of patient selection.

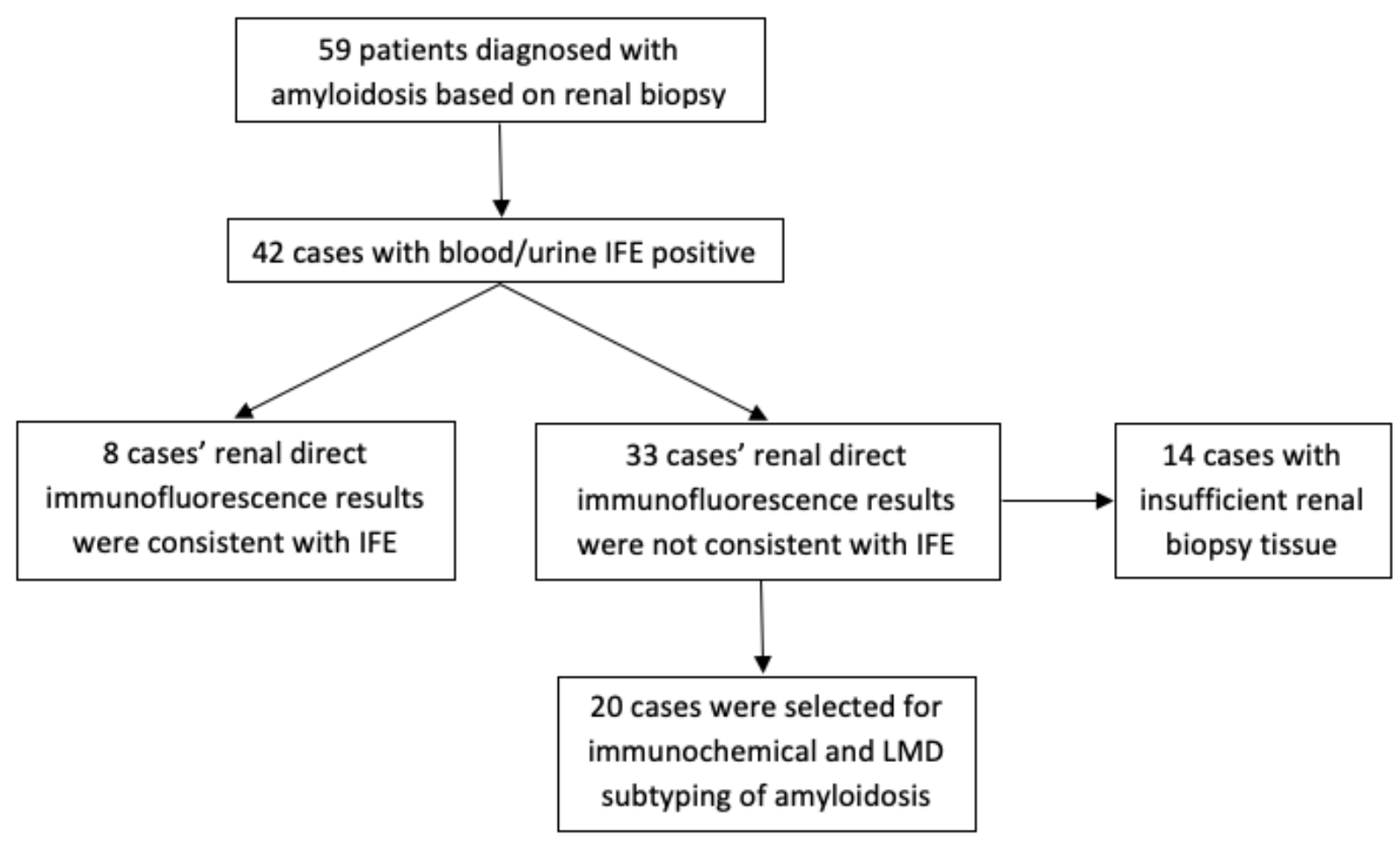


Table 2. Patients' clinical features, IFE results, renal biopsy pathology, results of immunochemical and LMD subtyping of amyloidosis.

Page 10/14 


\begin{tabular}{|c|c|c|c|c|c|c|c|c|}
\hline $\begin{array}{l}\text { Patient } \\
\text { ID }\end{array}$ & $\begin{array}{l}\text { Age } \\
\text { Range/Sex }\end{array}$ & $\begin{array}{l}\text { Blood/Urine } \\
\text { IFE }\end{array}$ & $\begin{array}{l}\text { Non- } \\
\text { structural } \\
\text { protein } \\
\text { deposition } \\
\text { site (HE } \\
\text { stain) } \\
\end{array}$ & $\begin{array}{l}\text { Congo } \\
\text { red } \\
\text { stain }\end{array}$ & $\begin{array}{l}\text { Fiber } \\
\text { deposition site } \\
\text { under electron } \\
\text { microscope }\end{array}$ & $\begin{array}{l}\text { Direct } \\
\text { Immunofluorescence } \\
\text { staining of } k \square \lambda\end{array}$ & $\begin{array}{l}\text { Renal } \\
\text { IHCк } \square \lambda \text { stain }\end{array}$ & $\begin{array}{l}\text { LMD } \\
\text { Subtyping }\end{array}$ \\
\hline P1 & $55-60 / \mathrm{M}$ & $\operatorname{IgG\lambda }$ & $\begin{array}{l}\text { Tubular } \\
\text { canal wall, } \\
\text { interstitial } \\
\text { vascular } \\
\text { wall and } \\
\text { peritubular }\end{array}$ & + & $\begin{array}{l}\text { Mesangial } \\
\text { area, GBM }\end{array}$ & $\mathrm{K} \square \lambda \square-\square$ & Fail & Fail \\
\hline P2 & $50-55 / \mathrm{M}$ & $F-\lambda$ & $\begin{array}{l}\text { Mesangial } \\
\text { matrix, } \\
\text { capillary } \\
\text { loops, small } \\
\text { vessel wall }\end{array}$ & + & $\begin{array}{l}\text { Mesangial } \\
\text { area, GBM }\end{array}$ & $\mathrm{K} \square \lambda \square-\square$ & Fail & AL \\
\hline P3 & $40-45 / F$ & $F-\lambda$ & $\begin{array}{l}\text { Arteriole } \\
\text { wall, } \\
\text { glomerular }\end{array}$ & + & $\begin{array}{l}\text { Mesangial } \\
\text { area, GBM }\end{array}$ & $\mathrm{K} \square \lambda \square-\square$ & $\lambda$ & AL \\
\hline P4 & $50-55 / \mathrm{M}$ & IgGk & $\begin{array}{l}\text { Arteriole } \\
\text { wall, } \\
\text { glomerular }\end{array}$ & + & $\begin{array}{l}\text { Mesangial } \\
\text { area, GBM }\end{array}$ & $\mathrm{K} \square \lambda \square-\square$ & $\mathrm{K}$ & AL-K \\
\hline P5 & $60-65 / F$ & $\operatorname{IgG\lambda }$ & $\begin{array}{l}\text { Interlobular } \\
\text { artery, } \\
\text { afferent } \\
\text { arteriole }\end{array}$ & + & $\begin{array}{l}\text { Mesangial } \\
\text { area }\end{array}$ & $\mathrm{K} \square \lambda \square-\square$ & $\lambda$ & AL- $\lambda$ \\
\hline P6 & $65-70 / \mathrm{M}$ & $F-\lambda$ & $\begin{array}{l}\text { Glomerulus, } \\
\text { arteriole } \\
\text { wall, } \\
\text { stroma }\end{array}$ & + & $\begin{array}{l}\text { Mesangial } \\
\text { area, GBM }\end{array}$ & $\mathrm{K} \square \lambda \square-\square$ & Fail & Fail \\
\hline P7 & $50-55 / F$ & $\operatorname{IgG\lambda }$ & $\begin{array}{l}\text { Arteriole } \\
\text { wall, } \\
\text { glomerular }\end{array}$ & + & $\begin{array}{l}\text { Mesangial } \\
\text { area, GBM }\end{array}$ & $\mathrm{K} \square \lambda \square-\square$ & $\lambda$ & $\mathrm{AL}$ \\
\hline P8 & 75-80/M & $\operatorname{IgG\lambda }$ & $\begin{array}{l}\text { Arteriole } \\
\text { wall, } \\
\text { glomerular }\end{array}$ & + & $\begin{array}{l}\text { Mesangial } \\
\text { area, GBM }\end{array}$ & $\mathrm{K} \square \lambda \square-\square$ & Fail & AL- $\lambda$ \\
\hline P9 & $65-70 / \mathrm{M}$ & $\operatorname{IgM} \lambda$ & $\begin{array}{l}\text { Arteriole } \\
\text { wall, } \\
\text { glomerular }\end{array}$ & + & $\begin{array}{l}\text { Mesangial } \\
\text { area }\end{array}$ & $\mathrm{K} \square \lambda \square-\square$ & $\lambda$ & AL- $\lambda$ \\
\hline P10 & $45-50 / \mathrm{M}$ & $F-\lambda$ & $\begin{array}{l}\text { Arteriole } \\
\text { wall, } \\
\text { glomerular }\end{array}$ & + & $\begin{array}{l}\text { Mesangial } \\
\text { area, GBM }\end{array}$ & $\mathrm{K} \square \lambda \square-\square$ & Fail & AL- $\lambda$ \\
\hline P11 & $65-60 / F$ & IgAK & $\begin{array}{l}\text { Arteriole } \\
\text { wall, } \\
\text { glomerular }\end{array}$ & + & $\begin{array}{l}\text { Under } \\
\text { epithelialium, } \\
\text { mesangial } \\
\text { area }\end{array}$ & $\mathrm{K} \square \lambda \square-\square$ & $\mathrm{K}$ & AL-K \\
\hline P12 & $55-60 / F$ & $\operatorname{Ig} A \lambda$ & $\begin{array}{l}\text { Arteriole } \\
\text { wall, } \\
\text { glomerular }\end{array}$ & + & $\begin{array}{l}\text { Epithelial and } \\
\text { mesangial } \\
\text { area }\end{array}$ & $\mathrm{K} \square \lambda \square-\square$ & Fail & AL- $\lambda$ \\
\hline P13 & $45-50 / F$ & $F-\lambda$ & $\begin{array}{l}\text { Arteriole } \\
\text { wall, } \\
\text { glomerular }\end{array}$ & + & $\begin{array}{l}\text { Mesangial } \\
\text { area, GBM }\end{array}$ & $\mathrm{K}+\square \lambda++$ & $\lambda$ & $\mathrm{AL}$ \\
\hline P14 & $65-70 / F$ & $F-\lambda$ & No & - & $\begin{array}{l}\text { Epithelial and } \\
\text { mesangial } \\
\text { area }\end{array}$ & $\mathrm{K} \square \lambda \square-\square$ & $\lambda$ & AL- $\lambda$ \\
\hline P15 & $55-60 / F$ & $F-\lambda$ & $\begin{array}{l}\text { Arteriole } \\
\text { wall, } \\
\text { glomerular }\end{array}$ & + & $\begin{array}{l}\text { Epithelial, } \\
\text { subendothelial, } \\
\text { mesangial } \\
\text { area }\end{array}$ & $\mathrm{K} \square \lambda \square-\square$ & Fail & AL- $\lambda$ \\
\hline P16 & $65-70 / \mathrm{M}$ & $\operatorname{IgG\lambda }$ & $\begin{array}{l}\text { Arteriole } \\
\text { wall, } \\
\text { glomerular }\end{array}$ & + & $\begin{array}{l}\text { Under } \\
\text { epithelialium, } \\
\text { mesangial } \\
\text { area }\end{array}$ & $\mathrm{K} \square \lambda \square-\square$ & $\lambda$ & AL- $\lambda$ \\
\hline P17 & $60-65 / M$ & F-K & $\begin{array}{l}\text { Arteriole } \\
\text { wall, } \\
\text { glomerular }\end{array}$ & + & $\begin{array}{l}\text { Epithelial, } \\
\text { subendothelial, } \\
\text { mesangial } \\
\text { area }\end{array}$ & $\mathrm{K} \square \lambda \square-\square$ & Fail & AL-K \\
\hline
\end{tabular}




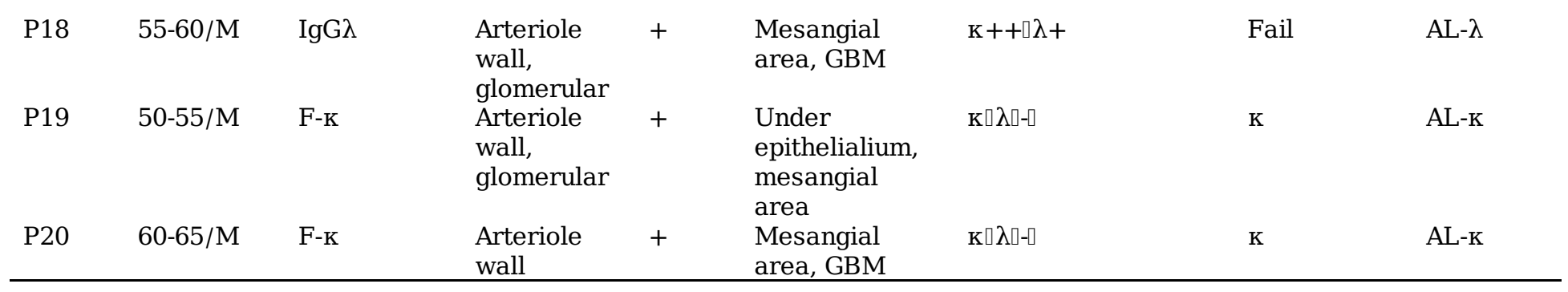

\section{Figures}
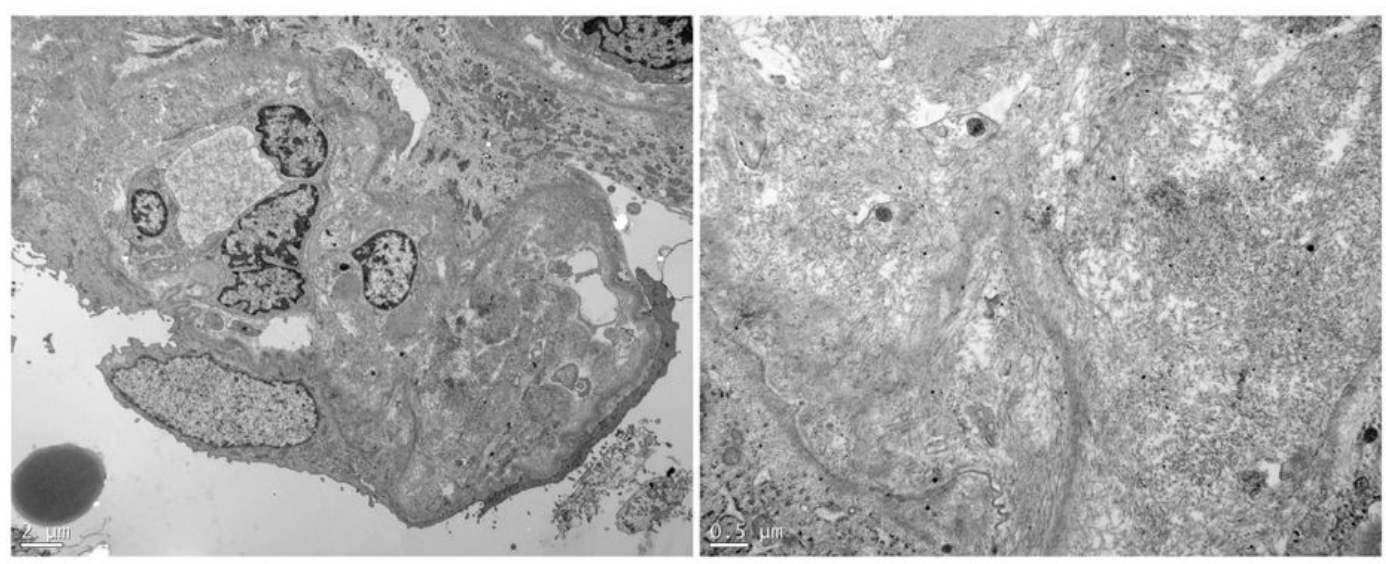

Figure 1 
Electron microscopy pictures of a confirmed amyloidosis subject. Amyloid appears as randomly oriented 10 to $12 \mathrm{~nm}$ thin fibrils, with a loose and flocculent background.
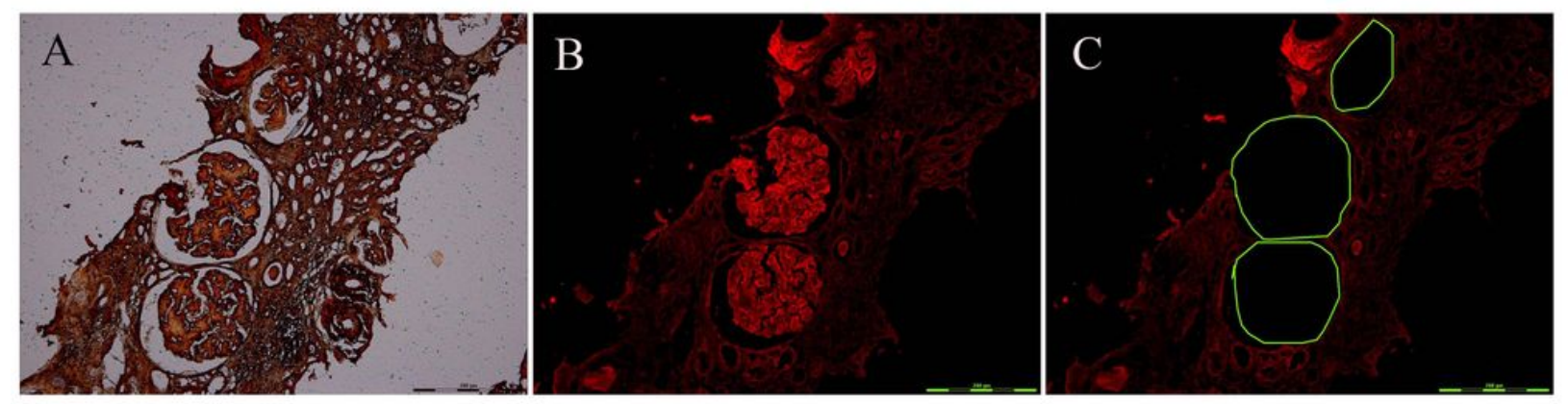

\section{Figure 2}

Process of laser microdissection. A. Congo red stain positive under light microscope. B. Congo red stain positive under fluorescence microscope. C. Empty space following microdissection of glomeruli.

A

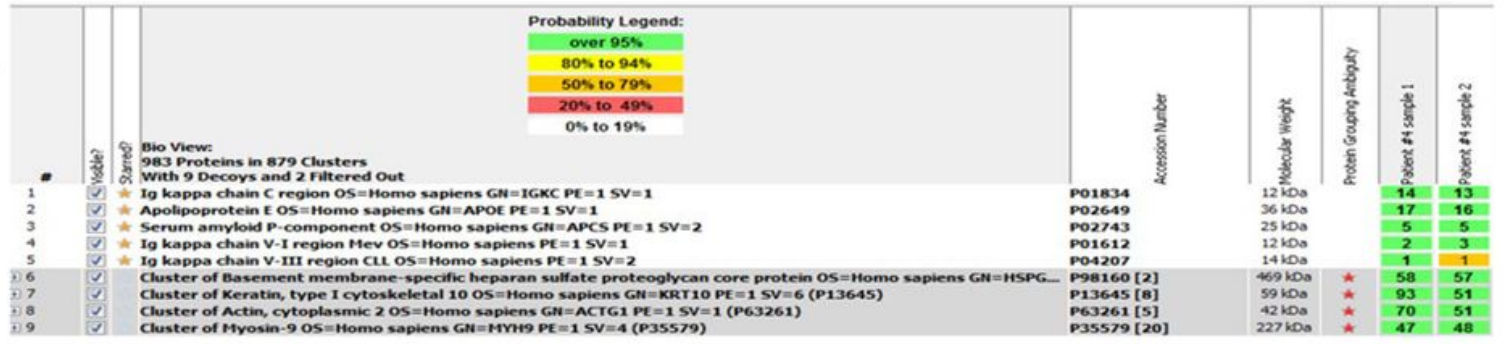

B P01834 (100\%), 11,608.6 Da

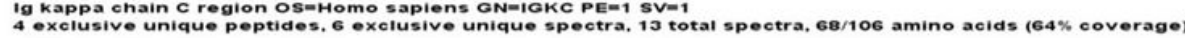

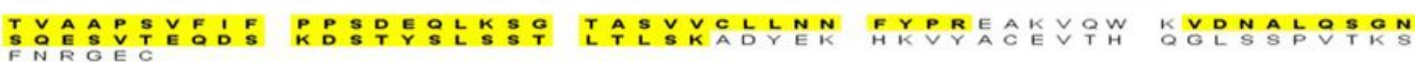

$\mathrm{C}$

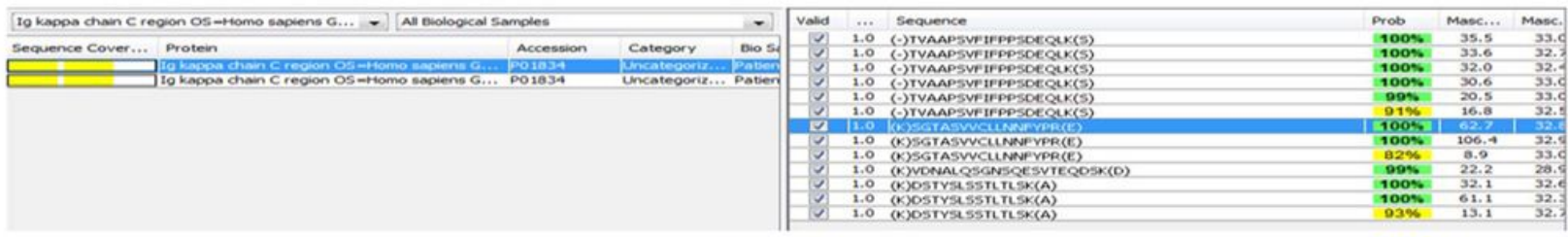

$\mathrm{D}$

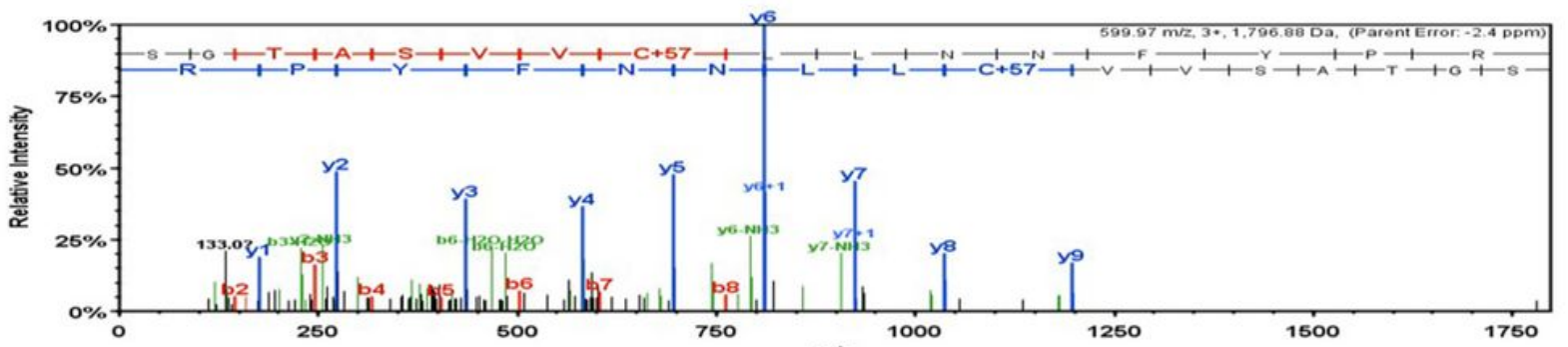

\section{Figure 3}

Representative mass spectrometry data by spectral analyses from a case of AL Kappa light chain amyloidosis. A. Mascot software presents renal biopsy mass spectrometry results; besides Apolipoprotein $E$ and serum amyloid $P$ component, the most abundant amyloidosis-related protein identified were Ig-Kappa. B. Mass spectrometry formation of the Ig-Kappa protein sequence detected in the sample. C. Peptides sequence of Ig-Kappa detected by LC-MS/MS. D. MS/MS spectrum of the (K) SGTASWCLLNNFYPR(E) peptide detected in the amyloid deposits. 
A

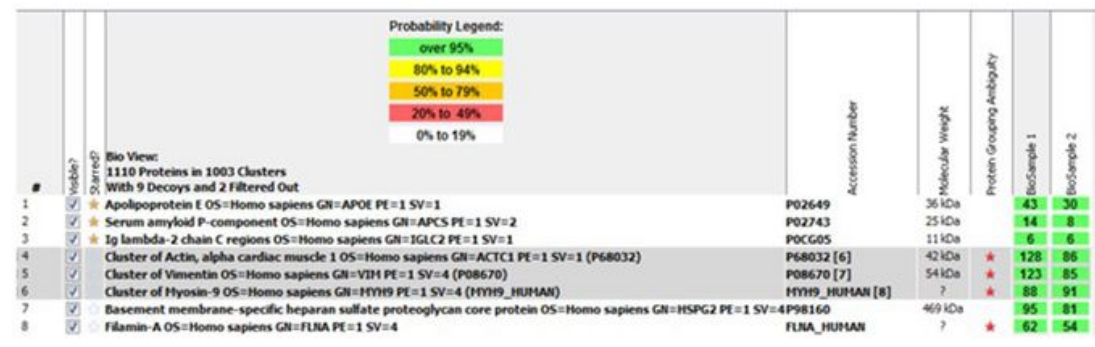

B

pocoss (1000). 11.2035203

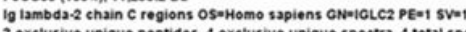

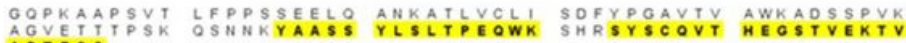

APTECS

C

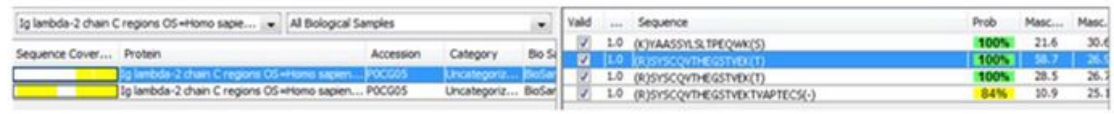

$\mathrm{D}$

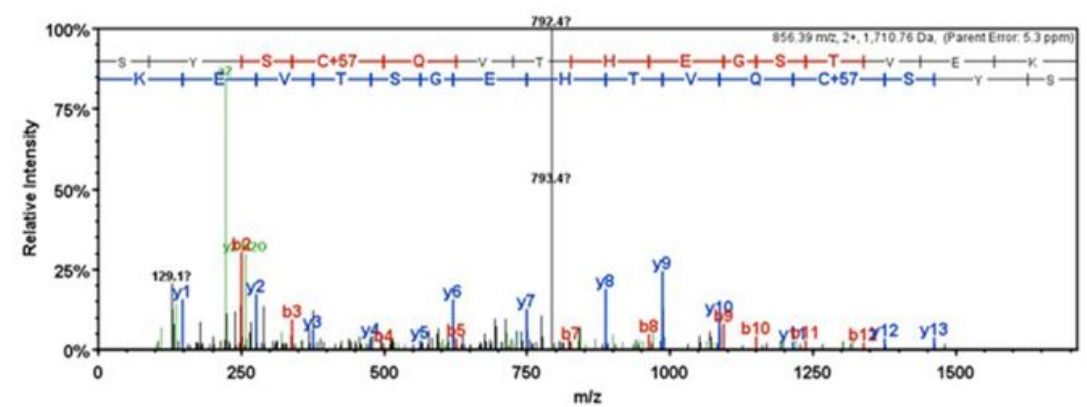

\section{Figure 4}

Representative mass spectrometry data by spectral analyses from a case of AL Lambda light chain amyloidosis. A. Mascot software presents renal biopsy mass spectrometry results, besides Apolipoprotein $E$ and serum amyloid $P$ component, the most abundant amyloidosis-related protein identified were Ig-lambda. B. Mass spectrometry formation of the Ig-lambda protein sequence detected in the sample. C. Peptides sequence of Ig-lambda detected by LC-MS/MS. D. MS/MS spectrum of the (R) SYSCQVTHEGSTVEK(T) peptide detected in the amyloid deposits. 